\title{
Increasing Visitor Knowledge of Park History and Natural Resources via Non-Traditional Recreation: An Exploratory Study of Quicksand Enthusiasts
}

\author{
Charles K. Mullins', Michael J. Bradley²*, Lashé D. Mullins' James N. Maples³ \\ ${ }^{1}$ Division of Humanities and Social Sciences, Alice Lloyd College, Pippa Passes, USA \\ ${ }^{2}$ Department of Recreation and Park Administration, Eastern Kentucky University, Richmond, USA \\ ${ }^{3}$ Department of Anthropology, Sociology, and Social Work, Eastern Kentucky University, Richmond, USA \\ Email: charlesmullins@alc.edu, `michael.bradley@eku.edu, lashemullins@alc.edu, james.maples@eku.edu
}

How to cite this paper: Mullins, C.K., Bradley, M.J., Mullins, L.D. and Maples, J.N. (2019) Increasing Visitor Knowledge of Park History and Natural Resources via Non-Traditional Recreation: An Exploratory Study of Quicksand Enthusiasts. Natural Resources, 10, 358-366.

https://doi.org/10.4236/nr.2019.109024

Received: August 9, 2019

Accepted: September 23, 2019

Published: September 26, 2019

Copyright () 2019 by author(s) and Scientific Research Publishing Inc.

This work is licensed under the Creative Commons Attribution International License (CC BY 4.0).

http://creativecommons.org/licenses/by/4.0/

\begin{abstract}
Sinkers are quicksand enthusiasts that crave the sensation of being trapped in deep mud while being sucked downward. Although humans have been interested in quicksand over the years (particularly through film), there remains a void of research into the meaning and value in the lives of those who engage in a recreational pursuit of quicksand, most notably the community of individuals who self-describe as sinkers. The purpose of this exploratory study was to examine if sinking can contribute to a participant's understanding of history and natural resources at state parks. In order to obtain a better understanding of the effects, a qualitative study was conducted in the summer of 2016 at Stephen C. Foster State Park, a state park adjacent to Okefenokee Swamp. The researchers exercised grounded theory techniques and inductive content analysis to analyze interview data and compile coded text into four main categories: learning, enjoyment, traveling, and economic impact. Findings suggest that participants believed their knowledge of park history and natural resources increased through a recreational pursuit of quicksand.
\end{abstract}

\section{Keywords}

Quicksand, Sinkers, Sinking, Qualitative Research, Park Management, History, Natural Resources

\section{Introduction}

Southeastern Georgia is home to numerous parks and historic sites attracting 
diverse recreation interests, including the legendary Okefenokee Swamp. The Okefenokee is the largest swamp in North America. It covers around 700 square miles of land and is protected by the Okefenokee National Wildlife Refuge [1]. Stephen C. Foster State Park, located on the banks of the Suwannee River, serves as a main entrance into the Okefenokee. The area is a haven for outdoor enthusiasts interested in canoeing, kayaking, boat tours, fishing, hiking, and camping. It also attracts recreationists from a lesser known type of outdoor recreation activity interested in searching for quicksand. This study contains new research and is a recreational topic that has never been explored in research until now. The only known previous research was conducted in 2016 and published a year later in JUPTRR [2].

Sinkers are quicksand enthusiasts who crave the sensation of being stuck in deep mud while also being sucked downward by liquefied soil [3]. Although not widely practiced, searching for and engaging quicksand is a socially-involved outdoor recreation activity made up of enthusiasts or adventure-based groups. However, the needs of this group have yet to be fully understood or explored, leaving a notable gap in the literature available on sinkers [2].

The purpose of this exploratory study was to examine participants' sinking experience and study how a recreational pursuit of quicksand may help participants learn about the history and natural resources of a park or historic site. The researchers hypothesized that quicksand participants would develop an increased understanding of components such as site history and natural resources by means of self-guided interpretation. The researchers also examined the sinking community and whether or not a recreational pursuit of quicksand may contribute to learning about the history and natural resources of Stephen C. Foster State Park and the Okefenokee National Wildlife Refuge.

\section{Review of Literature}

Quicksand is ordinary sand that is so heavily saturated with water that the friction between sand particles is reduced, making them unable to support any weight [4]. Quicksand is a mixture of sand and water, or sand and air that looks solid, but becomes unstable when disturbed by any additional stress. Quicksand merely requires soil and water to occur. When the ground becomes saturated, water molecules push apart the grains, reducing the intergranular friction and the soil's weight-bearing ability. The soil becomes quick when water pressure supporting the sand equals or surpasses the weight of the sand creating a floating suspension with the consistency of wet concrete that can trap a human being and not easily let go [4].

Numerous Hollywood movies and television programs have presented quicksand as a multi-faceted plot device. It is a gruesome deathtrap to capture the bad guy in Western films and a convenient deus ex machina to tie up loose plot ends. It becomes a chance to prove self-reliance through self-rescue from the imminent doom of the quicksand pit or a chance to demonstrate heteronormative 
norms by rescuing the female lead from the edge of death. Today, quicksand has all but evaporated from American movies and television, reasonably rejected by the very genre directors who once found it an indispensable plot device used to place characters in peril [3]. The use of quicksand in film media, however, has left an indelible mark in popular culture.

Falling into quicksand is not quite as dangerous as Hollywood directors and actors made it out to be. In reality, quicksand victims will float once they get about waist deep instead of being sucked below the surface according to a study by Khaldoun and associates [4]. As the study showed, people should be cautious and aware of the dangers of quicksand. However, it is effectively impossible for a conscious person immersed in quicksand to be drawn down completely under the surface. Still, a community of passionate enthusiasts exists that share a common interest in quicksand.

There is no real quicksand in the Okefenokee, as the swamp is actually a gigantic peat bog. Although these peat bogs may appear shallow from the surface, the decay underneath creates layers of muck that a person can easily sink into [5]. This creates an ideal location for sinkers to engage in this recreational activity. The study of a quicksand enthusiast's social world was based on the theoretical perspective of symbolic interactionism. From a phenomenological point-ofview, focusing on interpersonal interactions between quicksand enthusiasts is predominantly significant when attempting to understand interactions involved in the social processes of an outdoor recreation activity; even one as unique and non-traditional as seeking quicksand [2].

A community of passionate outdoor enthusiasts exists that share a strong mutual interest in the mysterious muck that once captured the fear and imagination of generations [3]. Many of these quicksand enthusiasts identify themselves as sinkers in what is a lesser-known type of outdoor recreation dubbed sinking [2]. This study, the first of its kind, explores the recreational activity of sinking and its effects on the history and natural resources of a state park. Although the research population in the present study consisted of quicksand enthusiasts, the researchers hope that the various conceptualizations and personal narratives will generalize to all types of recreation and should prove useful to both recreation managers and researchers.

\section{Methods}

Data was collected from sinkers visiting Stephen C. Foster State Park and subsequently the Okefenokee National Wildlife Refuge located in southeastern Georgia in the summer of 2016. The remote Stephen C. Foster State Park consists of roughly 80 -acres of land and offers main access to Okefenokee Swamp. Situated on the banks of the Suwannee River, the park was selected by the researchers due to its accessibility into the swamplands and its diversity of historic and natural resources [6].

The researchers incorporated grounded theory techniques developed by Glas- 
er and Straus [7] with the goal of examining participants' sinking experience and study how a recreational pursuit of quicksand may help participants learn about the history and natural resources of a park, historic site, and/or area. The researchers selected qualitative research methods to describe the experiences of the quicksand enthusiasts who fully immerse themselves in the learning and enjoyment of this lesser-known type of recreational activity.

As purposive sampling leads to "information rich cases," researchers used this technique and recruited study participants that were experienced sinkers [8]. Experience sinkers are quicksand enthusiasts that spend considerable amounts of time in quicksand areas, mostly in natural areas [2]. Qualitative inquiry was used to obtain information from participants about their sinking experience via on-site, semi-structured interviews. These qualitative methods enabled the researchers to more clearly understand the meaning and value of a recreational pursuit of quicksand and were appropriate for an exploration of attitudes, behaviors, and experiences [9].

The interviews occurred on-site at Stephen C. Foster State Park in June 2016. Interviews were recorded with a digital recorder. The duration of each participant interview was 45 to 90 minutes. Inductive content analysis was used to examine words and phrases used by each participant during the interviews. The researchers identified, coded, and classified themes from these words and phrases. The researchers used the process of constant comparison method during the data analysis and throughout follow-up interviews [7].

\section{Participants}

The researchers identified a small sample of individuals who share a common interest in sinking. The researchers recruited four quicksand enthusiasts who self-describe as being experienced sinkers. Each agreed to participate in on-site, semi-structured interviews. Participant A was a 45-year-old male from Northeast Florida. Participant B was a 51-year-old male and participant $\mathrm{C}$ was a 35-year-old female; both from Southeast Georgia. Participant D was a 54-yearold male from Northwest South Carolina. Lichtman [10] explained that the goal in qualitative research is to describe and interpret instead of generalize, and there are no specific rules on how many participants that researchers should study. As this is an exploratory study into an otherwise unexamined community, a small sample can provide a foundational understanding of the community for which to better understand the phenomena and promote further research. The study participants acknowledged and embraced the fact that their outdoor hobby is unique and not part of mainstream outdoor recreation.

\section{Findings and Discussion}

The researchers coded the narrative material provided from the interviews by breaking the text into relatively small units of content and submitted them to descriptive treatment. After reducing volumes of recorded material into more 
manageable data, the researchers discovered four categories emerged through inductive content analysis. The categories included enjoyment (44\% of coded text), learning (32\%), traveling (13\%), and economic impact (11\%).

\subsection{Enjoyment}

The researchers discovered that participants derived substantial enjoyment from the act of sinking. The Okeefenokee Swamp provided a unique challenge to test their knowledge and skills, given that it is not a true example of quicksand. The researchers applied grounded theory techniques developed by Glaser and Straus [7] to the enjoyment participants experienced while visiting Stephen C. Foster State Park and the Okefenokee Swamp. As applied to the social world of sinking, overall factors observed would include each participant having a clear goal to be obtained (searching for quicksand), receiving direct feedback (finding or failing to find sinking hotspots in selected geographic areas), and feeling rewarded (when the quicksand, or in the case of Okeefenokee Swamp, selected peat bog areas, is discovered).

Findings suggest that participants derived a sense of accomplishment from the sinking experience and, as is often in their social world, the enjoyment is heightened by getting into the muck itself. A social world has been defined as providing a structure of an alternative value system, which contains its own rules and systems [11]. Participant D stated, "To say that I love swamps is an understatement. I've hiked miles through some of the most amazing terrain in the country, but I've always wanted to visit Okefenokee. I can scratch this one off the bucket list." Findings also suggest that the participants enjoyed the human interactions associated with visiting Stephen C. Foster State Park, and therefore, view sinking as a social activity to be done with friends and family. Participants B and C are a husband and wife team of sinkers who have been in recreational pursuit of quicksand together for nearly fifteen years. Participant C explained, "My (spouse) and I like to make sinking excursions into a vacation. We love to camp out, bring a small grill and a large cooler, and spend about a week outdoors. We like to do other things on the parks too. We hike, ride bikes, fish and swim." Engaging in conversations with park staff is often on the daily agenda as participant $B$ explained, "The park staff are usually very kind and helpful. I like talking to them because that's the best way to learn about the park." All participants reported that they found value in communicating with the park staff because they explained things about park history and natural resources that otherwise would be unknown to the sinkers.

\subsection{Learning}

The researchers explored the effects of sinking on learning about the history and natural resources in Stephen C. Foster State Park and the nearby Okefenokee National Wildlife Refuge. The differing dimensions of participant experiences and personal stories were examined with the concept of learning being one of the main categories to emerge from the interviews. Participants fondly recalled 
learning about the park and surrounding swampland, thus fostering an awareness and understanding of Georgia's State Parks and Historic Sites and local natural ecosystems in an intrinsically rewarding manner. Researchers argue that the learning process itself and not merely the result, should be interesting, if one seeks higher motivation among learners [12].

Findings suggest that participants visiting the sites to find quicksand learned a great deal about the history and natural resources of Stephen C. Foster State Park and the Okefenokee Swamp. Participant A explained, "I learned so much about the area's history during our weekend camping trip. From alligators and wildfires to loggers and moonshiners, I discovered much more on this trip than what I set out to find." Participant A added, "You won't actually find quicksand here, but rather peat bogs, which is ground of wet, decomposing vegetation." This quote helps identify one example of what information was learned through engaging in sinking. Additionally, Participant B recalled his surprise after learning that there was once a town on Billy's Island located in the middle of Okefenokee National Wildlife Refuge, which included several homes, a theater, and a doctor's office. “I couldn't believe it. An entire town made of logging camps located on an island in the middle of the swamp. Unfortunately, the only indication today that anyone once lived there is a cemetery and old rusted metal, but it's a fascinating piece of our American history."

\subsection{Traveling}

The researchers discovered that travel to the Okefenokee National Wildlife Refuge is highly recommended among sinking enthusiast social networks. As Participant A stated, "The park offers a window of opportunity for a Southern Georgia swamp adventure and where there is swamp, there are opportunities to sink." The researchers observed that participants appear to be engaging in experiential travel as they exhibited a connection to the environment, history, staff, and surrounding community, in addition to their mutual recreational interest. Experiential travel is an approach to travel that goes beyond typical tourist attractions, perhaps connecting visitors with a park and its history and natural resources on a much deeper level [13].

Findings suggest that participants travelled more frequently due to their recreational interest in sinking as they like to explore new sinking hotspots as well as visit other parks and natural areas. Participant $\mathrm{C}$ noted, "I've been to many remote areas in many states that I never would have visited without wonderful access provided by the state parks systems. Sometimes I'll pick a hotspot that I haven't been to and after I find the sinkhole I'll visit other nearby parks to see what cool features they offer." Experiential travel is about valuing the experiences at a park or historic site and connecting with the environment, history and staff. The researchers observed the participants celebrating diversity in recreational activities and their travel reflects this notion. Participant B explained, "the beauty of Georgia State Parks and Historic Sites is impossible to ignore, and 
visiting different parks is a great opportunity to learn about things like history, geology, and nature."

\subsection{Economic Impact}

Parks continue to be an economic engine for their communities as the participants ponder the effect of their financial contributions to Georgia State Parks and Historic Sites. The services and programming offered by local and regional parks greatly enhance the quality of life of the surrounding community [14]. Being a significant contributor to economic activity and employment adds to the impressive list of benefits that the state park systems bring to their towns, cities, counties and regions [15] [16].

Findings suggest that participants were aware of their economic impact by visiting the park and local community. Participant A explained, "I understand the need to charge a park pass or camping fee as those funds typically get redirected back to the park itself. Whether its new picnic tables or trash cans, that money basically goes for anything the park needs to help sustain itself." Participant D added, "I'm on a tight budget at home but I try to spend money in the parks because I honestly feel that it is good money spent. I like to think my money is helping with maintenance projects or paying park staff."

\section{Conclusions and Implications}

The results of this study indicate the value of sinking as a learning tool in parks and natural areas. As many parks and historic sites strive to implement education and interpretation, sinking can apprise participants with the areas they are visiting. Furthermore, participants in this study experienced a better understanding of the history and natural resources of Stephen C. Foster State Park and the Okefenokee National Wildlife Refuge, while engaged in a unique recreational pursuit. In addition, the results of this study indicated that participants experienced learning and enjoyment in sinking while acknowledging their recreational pursuit of quicksand as a social activity. As an activity that draws in nontraditional visitors, the results of this study indicate that sinking creates an opportunity to educate guests on history, culture, and natural resources within the parks system. The results of this study indicate that sinking serves as a motivator for participants to only travel to visit various parks and natural areas and that sinkers are returning to those same areas providing their visit merits positive recreational experiences. Lastly, the results of this study indicate that sinking may have positive effects on the economy as participants spend money at the parks and historic sites and shop and purchase goods within the local communities.

This study serves as the first entry in the research of the recreational activity of sinking in terms of how pursuit of the activity can educate visitors about the history and natural resources of a state park or historic site. No other academic research has been published on the non-traditional recreational pursuit of quicksand enthusiasts. The researchers hope the findings of this study bring more at- 
tention to sinking as a recreational activity and inspire other researchers to conduct further studies and gather new observations that may guide future research. Lastly, park management could use the information within this study to better market quicksand as a sustainable use of natural resources to specific audiences. The market segment of quicksand seekers has much room to grow, the sustained impact on the resource is low (carrying capacity is high), and the activity seems to connect visitors and various aspects of the park in learning about history and natural resources.

\section{Conflicts of Interest}

The authors declare no conflicts of interest regarding the publication of this paper.

\section{References}

[1] Cohen, A.D., Andrejko, M.J., Spackman, W. and Corvinus, D. (1984) Peat Deposits of the Okefenokee Swamp. The Okefenokee Swamp, Southern Georgia, FL, 493-553.

[2] Mullins, C.K. and Bradley, M.J. (2017) The Social World of Sinkers: A Recreational Pursuit of Quicksand. Journal of Unconventional Parks, Tourism \& Recreation Research, 7, 11-15.

[3] Engber, D. (2010) Terra Infirma: The Rise and Fall of Quicksand. http://www.slate.com/articles/health_and_science/science/2010/08/terra_infirma.html

[4] Khaldoun, A., Eiser, E., Wegdam, G.H. and Bonn, D. (2005) Liquefaction of Quicksand under Stress: A Person Trapped in Salt-Lake Quicksand Is Not in Any Danger of Being Sucked under Completely. Nature, 437, 635. https://doi.org/10.1038/437635a

[5] Cohen, A.D. (1974) Petrology and Paleoecology of Holocene Peats from the Okefenokee Swamp of Georgia. Journal of Sedimentary Petrology, 44, 716-720. https://doi.org/10.1306/74D72AEA-2B21-11D7-8648000102C1865D

[6] Stephen, C. (2016) Foster State Park. http://www.gastateparks.org/StephenCFoster

[7] Glaser, B.G. and Strauss, A.L. (1967) The Discovery of Grounded Theory: Strategies for Qualitative Research. Aldine Publishing, Chicago, IL.

[8] Patton, M.Q. (1990) Qualitative Evaluation and Research Methods. Sage Publications, Inc., Newbury Park, CA.

[9] Maxwell, J.A. (2012) Qualitative Research Design: An Interactive Approach. Sage Publications, Inc., Thousand Oaks, CA.

[10] Lichtman, M. (2010) Understanding and Evaluating Qualitative Educational Research. Sage Publications, Inc., Thousand Oaks, CA.

[11] Abercrombie, N. and Longhurst, B.J. (1998) Audiences: A Sociological Theory of Performance and Imagination. Sage Publications Inc.

[12] Rieber, L.P., Smith, L. and Noah, D. (1998) The Value of Serious Play. Educational Technology, 38, 29-37.

[13] Peak and Skift (2014) The Rise of Experiential Travel, Skift Report 2014. https://skift.com/wp-content/uploads/2014/06/skift-peak-experiential-traveler-repo rt1.pdf

[14] Harnik, P. and Crompton, J.L. (2014) Measuring the Total Economic Value of a Park System to a Community. Managing Leisure, 19, 188-211. 
https://doi.org/10.1080/13606719.2014.885713

[15] Maples, J.N. and Bradley, M.J. (2017) Economic Impact of Mountain Biking in the Nantahala and Pisgah National Forests. Outdoor Alliance.

[16] Maples, J.N., Sharp, R.L., Clark, B.G., Gerlaugh, K. and Gillespie, B. (2017) Climbing out of Poverty: The Economic Impact of Rock Climbing in and around Eastern Kentucky's Red River Gorge. Journal of Appalachian Studies, 23, 53-71. https://doi.org/10.5406/jappastud.23.1.0053 